\title{
Borgerløn: Kan det nu betale sig?
}

\author{
Kristian Kongshøj, postdoc ved Institut for Statskundskab, Aalborg Universitet
}

Borgerlønnen er blevet revitaliseret $i$ de senere års debat, blandt andet som muligt redskab til at bekompe ulighed eller polarisering og segmentering på arbejdsmarkedet. Denne artikel diskuterer, hvorledes en lav, delvis borgerløn i kombination med reducerede ydelser kan realiseres, mens en fuld og generøs borgerløn vil krove beskatning og omfordeling på et hidtil uset niveau. Det understreges også, at borgerlønnen ikke i sig selv vil løse polariserende tendenser på arbejdsmarkedet. En lav eller delvis borgerløn kan endog understøtte udbredelsen af et lavtlønnet og usikkert prekariat.

\section{Indledning}

Borgerlønnen er en universel, individuel ydelse, der udbetales regelmæssigt uden betingelser (Widerquist m.fl. 2013, Christensen 2000). I de mere normativt ambitiøse udlægninger skal den endvidere være tilstrækkelig til, at man på et beskedent niveau skal kunne leve af den uden at tage lønarbejde. Dette står i modsætning til traditionelle overførselsindkomster, der i et eller andet omfang hviler på behovs- og indkomstprøvning, og ofte i tilgift er betinget af krav om bestemte handlinger. Man kan udlægge forskellige varianter af borgerløn og borgerlønslignende ydelser (Standing 2017; Widerquist m.fl. 2013; Christensen 2000; Atkinson 1996), men denne artikel vil ikke beskæftige sig indgående med disse ved siden af ovenstående korte definition. Det grundlæggende er, at borgerlønnen vil bryde med den forbindelse, der hidtil har været mellem forskellige former for indkomst og status på arbejdsmarkedet. Også på dansk har forskellige terminologier været anvendt, eksempelvis 'ubetinget basisindkomst' (Christensen 2000), men i denne artikel anvendes blot 'borgerløn'. Jeg vil senere kort henvise til idéen om negativ indkomstskat, som adskiller sig fundamentalt fra borgerlønnen ved at være indkomstgradueret. Idéen her er, at man over en vis indkomstgrænse betaler skat. Under grænsen begynder man i stedet gradvist at modtage et tilskud, indtil man modtager den fulde ydelse, hvis man ingen selvstændig indkomst har.

Som idé har borgerlønnen ikke blot årtier, men århundreder på bagen. Det er endda muligt at sige årtusinder og trække tråde tilbage til antikkens Grækenland og figurer som Aristoteles eller Perikles (Standing 2017). I løbet af de seneste få år har idéen igen fået politisk momentum; der er lokale eksperimenter med borgerløn eller borgerlønslignende ydelser undervejs (eller på vej) i Finland, Holland, Canada og Tyskland, og der er flere private eller NGO-drevne på vej i USA. Der er ligeledes nye eksperimenter i 
udviklingslandene Kenya og Uganda (McFarland 2017). Endnu flere officielle rapporter, præliminære planer og tænketanksrapporter kunne opremses.

I Danmark er debatten fortsat lidt af et nichefænomen. Blandt Folketingets partier vil Alternativet undersøge mulighederne for en borgerløn nærmere, men ellers er det vanskeligt at finde betydningsfulde politiske aktører, der er optaget af idéen. I Danmark har debatten bølget lidt frem og tilbage siden storhedstiden for 40 år siden omkring Oprør fra midten (Meyer, Petersen \& Sørensen 1978), men mestendels på et ret lavt blus (se Christensen, 2000, eller opsummeringen i Christensen, 2017, for en gennemgang af den danske debathistorik).

Borgerlønnen kan imødekomme en efterspørgsel på politiske idéer hinsides hverdagspolitik, idet den som diskurs rummer en række fortællinger om, hvordan den kan løse en række presserende problemer, såsom økologisk krise, ulighed og arbejdsmarkedssegmentering. Samtidig lover den langt større individuel frihed i forholdet til både stat og marked, og siges at afspejle mere retfærdige principper for indkomstfordeling, da velstand og indkomst kun i begrænset omfang kan henføres til individuelle handlinger og færdigheder. På alle disse områder er der væsentlige debatter mellem borgerlønsoptimister og-skeptikere.

Der er dog en mangel på kritiske diskussioner på disse områder. På dansk har vi i nyere tid kun set nogle få bøger om emnet, og disse er skrevet af erklærede borgerlønsforkæmpere (Christensen 2017; Christensen \& Ydesen 2007; Larsen 2002; Christensen 2000). På baggrund af indsigter fra den nyere litteratur er denne artikels mål at bidrage til denne debat ved at diskutere to vigtige spørgsmål, der dominerer i debatten om borgerlønnens betydning for økonomi og ulighed. For det første er det spørgsmålet om finansiering, samt for det andet segmentering på arbejdsmarkedet. Dette er to væsentlige spørgsmål, når det handler om at undersøge, hvorvidt en borgerløn er realiserbar og ønskelig, og dermed også den praktisk anlagte titel "Kan det nu betale sig?". Christensen (2000) har tidligere beskrevet nogle forskellige diskurser om borgerløn, og én af disse var den politisk-teknisk orienterede. Med dette udgangspunkt kan man fremstille borgerløn som et svar på aktuelle tendenser, og som en idé, der ligger i forlængelse af eksisterende mål og institutioner. Denne artikel diskuterer nogle af de vigtigste spørgsmål, som et sådant perspektiv giver anledning til.

Denne tilgang betyder omvendt også, at jeg ikke indgående vil beskrive og diskutere borgerlønnens indre normative logikker vedrørende retfærdighed og frihed eller autonomi (se f.eks. Standing 2017; Widerquist m.fl. 2013; Christensen 2000; Van Parijs 1997; Gorz 1997). Vi vil heller ikke komme i berøring med andre debatter som eksempelvis borgerlønnens mulige grønne potentialer (se f.eks. Andersson 2009; Goodin 2001), eller borgerlønnens muligheder for at fremstå retfærdig og dermed opnå legitimitet og opbakning i den bredere offentlighed (se f.eks. Rothstein 2017; Barry 2001; Widerquist 1999).

I stedet vil vi gå direkte til diskussionen af de to underspørgsmål i hvert sit hovedafsnit. Disse vil understrege borgerlønnens væsentlige svagheder, men omvendt også at den ikke blot kan afvises uden videre diskussion. 
Finansiering: Dilemmaet mellem tilstrækkelighed og realiserbarhed?

Finansieringsspørgsmålet er nok borgerlønnens væsentligste barriere. Borgerlønnen skal finansieres ved en eller anden grad af omfordeling af indkomster og kapital. En evt. forøgelse af den samlede indkomst, der ikke er begrundet i den eksisterende produktion, vil i konventionel optik medføre inflationspres, selvom det kan diskuteres i hvor høj grad, det udelukkende vil omsættes til inflation (Flassbeck 2017; Harvey 2011).

Det eksisterende niveau for skattefinansierede udgifter til overførselsindkomster svarede i 2016 til, at alle danskere over 15 år i gennemsnit modtog $61.500 \mathrm{kr}$. brutto, dvs. ca. 20\% af gruppens gennemsnitsindkomst på 312.600 kr (Danmarks Statistik 2017). OECD (2017) viser for medlemslandene generelt, at en simpel universel fordeling af eksisterende udgifter til overførsler ville medføre en borgerløn, der ligger langt under de enkelte landes relative fattigdomsgrænser, og i næsten alle tilfælde også signifikant under niveauet for de nuværende kontanthjælpslignende ydelser. Disse hurtige overslag er selvfølgelig noget misvisende, idet udgifterne til en borgerløn afhænger af skattesystemet. Højere indkomster vil på et eller andet tidspunkt have betalt et tilsvarende beløb tilbage i skat. Den fulde borgerløn, der erstatter alle andre ydelser, foreslås typisk i sammenhæng med en flad indkomstskat, hvilket i de fleste tilfælde faktisk vil være mere omfordelende end eksisterende skatte- og ydelsessystemer (Standing 2017; Kela 2016). Dertil kommer ændrede administrative omkostninger, samt hvorvidt niveauet for andre offentlige udgifter vil ændre sig efter en borgerløn.

At en borgerløn alligevel kan medføre langt højere niveauer for personbeskatning er blevet påpeget af en lang række mere grundige studier og modelberegninger. I Finland blev der forud for det igangværende eksperiment lavet en udredning med et par forskellige modeller for fuld borgerløn på hhv. 1500 og $1000 \mathrm{EUR} / \mathrm{md}$., skattefrit. De ville begge flerdoble eksisterende udgifter til overførsler og medføre behov for en flad beskatning på hhv. $79 \%$ og $60 \%$ af andre personindkomster fra både arbejde og kapital (Kela 2016). Det er også værd at huske, at Økonomiministeriets Økonomiske Sekretariat i 1993 under Marianne Jelved fik beregnet konsekvenserne af en beskattet borgerløn på enten 130.000 kr. eller $90.000 \mathrm{kr}$. om året, hvor man i den sidste model bibeholdte visse supplerende ydelser. Disse ville hæve marginalskatterne til et spænd på hhv. 74-90 \% og 85-100 \%. Beregningerne blev dog kritiseret for at være meget mangelfulde, bla. havde man ikke nedreguleret dagpenge mv., ligesom man ikke anvendte det bredere skattegrundlag fra 1993 (Christensen 2000). På omkring samme tid forventede en række forskellige alternative modeller fra de partipolitiske baglande i SF, Det Radikale Venstre og De Grønne typisk en samlet indkomstbeskatning på omkring $70 \%$.

Disse eksempler illustrerer, at en fuld og generøs borgerløn skal suppleres med andre kilder til finansiering ved siden af øget indkomstbeskatning. Den internationale debats fremmeste akademiske stemme ved siden af Guy Standing, Philippe Van Parijs (1990), anerkendte, at en borgerløn måtte medføre højere skatter på indkomster. Fra den internationale debat kan nævnes flere forslag til at finansiere en beskeden borgerløn i kombination med andre finansieringskilder, hvor indkomstskatterne ikke bliver så høje 
som i ovenstående (se bl.a. Miller 2017; Major 2016; Acarons, Pañella \& Mélich 2014; Rankin 2012; Höglund 2007). Som regel står den konkrete udformning og sammensætning af disse andre finansieringskilder dog lidt hen i det uvisse, men der nævnes forskellige kombinationer af beskatning af forbrug, formuer, profitter, kapital generelt (herunder ofte ejendomsbeskatning) samt nedprioritering af andre offentlige udgifter (Standing 2017; Miller 2017). Der har i den nyere debat især været fokus på nogle af de former for 'kapital', der driver store økonomiske transformationer netop nu, herunder beskatning af data, som stilles gratis til rådighed af de sociale mediers brugere (og som videresælges til tredjeparter), samt automatisering (eksempelvis har Bill Gates gjort sig til fortaler af en skat på 'robotter') (The Economist 2017a, 2017b; Rhodes 2017). Formålet med beskatning af disse og andre kapitalformer er desuden via makrostrukturel omfordeling at bekæmpe tendenserne til øget ulighed i næsten alle udviklede lande. Mange af disse mulige skattekilder spiller dog allerede en væsentlig rolle i det samlede beskatningsgrundlag, og det vil være en udfordring at indrette dem sådan, at de ikke blot skader eller overvæltes på almindelige indkomster. Der er naturligvis også bekæmpelse af skattely og -unddragelse (Zucman 2017), men dette er et mål uanset borgerløn.

Den sociale dividende er en borgerlønsmodel, der løser finansieringsspørgsmålet ved ikke på forhånd at fastlægge udbetalingens størrelse, som i stedet afgøres af indtægterne fra valgte finansieringskilder, der typisk foreslås akkumuleret i en fondsstruktur. Dette var sådan set modellen i et af de klassiske værker, som udlagde nogle af de væsentligste argumenter for borgerlønnen, nemlig Thomas Paines Agrarian Justice fra 1795 (Standing 2017). Paine forestillede sig, at afkastet fra besiddelse af jord og ejendomme skulle deles af fællesskabet. Modellen har et virkeligt eksempel i Alaskas Permanent Fund Dividend, som årligt siden 1982 har udbetalt en dividende til alle borgere på basis af en del af delstatens indtægter fra olie (Widerquist \& Sheahen 2012). De seneste 20 år har beløbet som oftest være på mellem 1000 og 1500 USD om året per person (inkl. børn). Dividenden er ikke stor nok til at udgøre et fundament for det daglige levegrundlag. Det viser også, at det er en økonomisk udfordring at definere en dividende, der kan leve op til borgerlønnens mest basale ambitioner.

Som nævnt skal vi trods alt nå frem til en konklusion om, at en delvis, begrænset borgerløn i kombination med traditionelle velfærdsydelser synes tæt på realiserbar inden for rammerne af de eksisterende skattekilder og -niveauer. Dette blev eksempelvis konklusionen i førnævnte finske udredning, der anbefalede en ganske basal ydelse på 560 EUR/md., skattefrit, der suppleres af de eksisterende ydelser således at alle 2000 arbejdsløse deltagere i eksperimentet har samme indkomst som andre arbejdsløse (Kela 2017, 2016). Denne model, hvor de 560 EUR beholdes uanset efterfølgende indkomst, vil alligevel medføre et finansieringsbehov på 11 milliarder Euro hvis den bliver udbredt til hele Finland (Kela 2016). Andre modeller for en delvis borgerløn, der ligeledes medfører et betragteligt øget finanseringsbehov kan nævnes fra Storbritannien og Danmark (BIEN Danmark 2017; Reed \& Lansley 2016). Ét af BIEN Danmarks forslag indebærer eksempelvis en delvis borgerløn på $6000 \mathrm{kr} . / \mathrm{md}$. med en indkomstskat på 58 \%. OECD (2017) har forsøgt at udregne budgetneutrale, delvise borgerlønsmodeller for fire lande (Finland, 
Frankrig, Italien og Storbritannien), hvor boligstøtte bibeholdes, mens de fleste andre ydelser fjernes eller reduceres, inklusive skattefradrag. I forhold til de eksisterende systemer ville denne ydelse skabe store grupper af både vindere og tabere på tværs af indkomstskalaen. Samlet set ville en mindre andel på 2-4 \% af befolkningen blive hævet over de enkelte landes respektive fattigdomsgrænser, mens lidt flere, 3-7 \%, ville ryge under fattigdomsgrænserne.

IMF (2017) har mere generelt diskuteret, at der især er mange potentielle tabere blandt modtagere af de eksisterende ydelser i den type udviklede velfærdsstater, hvor ydelserne inkluderer relativt mange og er relativt generøse. Især i mange udviklingslande har de eksisterende sociale udgifter omvendt haft regressive effekter, da en lille gruppe insidere fra den højere middelklasse har haft størst fordel af det eksisterende system. Her kan en borgerløn være et progressivt fremskridt, selv med de eksisterende, begrænsede udgiftsniveauer. I den danske velfærdsstat kunne det omvendt være særligt svært at implementere en borgerløn uden at væsentligt flere stilles ringere end i dag, hvis ambitionen er en nogenlunde omkostningsneutral borgerløn. Det er dog en sandhed med store modifikationer, at de eksisterende overførselsindkomster skulle være særligt generøse og udgiftstunge i Danmark og Norden generelt (Kongshøj 2015). Alligevel er det rigtigt, at når vi ser på andel inkluderede i sikkerhedsnettet, og tager den høje beskæftigelse med, har Danmark frem til 1990erne stået som det land, der var bedst i Europa til at sikre, at meget få havde hverken arbejds- eller overførselsindkomst (CESifo 2003). I de senere år har en række velfærdsreformer været med at ændre lidt på billedet. Siden 2009 er antallet af borgere, der ikke har en indtægt fra hverken job eller understøttelse, steget fra 130.000 til mere end 160.000 (Arbejderbevægelsens Erhvervsråd 2018). Der er dog ingen tvivl om, at det især er i et land som Danmark, at man kan opleve et svært dilemma mellem borgerlønnens tilstrækkelighed for den enkelte (sammenlignet med de eksisterende ydelser) og den samlede umiddelbare økonomiske realiserbarhed.

Selvom vi med en delvis borgerløn således er tættere på noget mere realiserbart, når vi konservativt holder os inden for rammerne af de eksisterende skattesystemer, ville der således stadig væsentlige udfordringer. Mange borgerlønsforkæmpere har en yderst basal borgerløn som deres udgangspunkt. Dette omfatter også Standing (2017, 3), der lægger vægt på at en 'basic income' skal være 'basic', ligesom han skriver, at total indkomstsikkerhed ikke er "...hverken ønskeligt eller muligt". Dermed skal den heller ikke afløse eller eliminere alle hidtil eksisterende velfærdsydelser. I alt fald ikke i første omgang. Borgerlønnen kan så udbygges efter sin implementering, hvis det bliver muligt. Sådanne meget beskedne skridt betyder selvfølgelig, at man ikke fra starten vil indfri mange af de store ambitioner, men det ville også afspejle velfærdsstatens hidtidige historie, hvor det tog årtier at nå frem til steder, der kunne forekomme utopiske, da man startede.

Til sidst skal det anerkendes, at alle forsøg på at estimere omkostningerne ved en borgerløn naturligvis har en afgørende ubekendt faktor i form af folks adfærd efter en borgerløn. Med hensyn til arbejdsudbud er det en udbredt indvending, at langt flere vil træde ud af arbejdsmarkedet ved en ubetinget og generøs borgerløn. Som nævnt vil en 
borgerløn dog kunne skabe et komplekst billede af vindere og tabere, og der vil således også kunne være betydelige heterogene effekter på arbejdsudbud, ligesom adfærdsforskning har understreget, at økonomiske incitamenter spiller en begrænset rolle i tilgift til andre former for motivation (Dohmen 2014; Kamenica 2012). Der er meget begrænset mulighed for at hente erfaring fra tidligere eksperimenter. Eksperimenterne i USA og Canada i 1968-1980 var alle eksempler på en negativ indkomstskat, som adskiller sig fundamentalt fra borgerlønnen ved at være en indkomstgradueret ydelse. Efterfølgende studier fandt i forskellig grad en nedgang i mængden af samlede arbejdstimer, som afspejlede lidt længere arbejdsløshedsperioder, samt at især mødre reducerede deres arbejdstid, og i ringere grad at folk trådte helt ud af arbejdsmarkedet (Widerquist 2005). Tidligere NGO-drevne, borgerlønslignende eksperimenter i Namibia og Indien dokumenterede øget økonomisk aktivitet, men konteksten er naturligvis en helt anden, og bør snarere indgå $\mathrm{i}$ den større debat om betingede versus ubetingede fattigdomsbekæmpende ydelser i udviklingsøkonomierne (Hanlon, Barrientos \& Hulme 2010).

\section{Frigørelse eller segmentering af arbejdskraften?}

Især venstrelibertære tænkere vil anvende borgerlønnen som frigørelse af arbejdskraften. Målet er at afbøde oplevelsen af stigma eller tab af autonomi ved ikke at være på arbejdsmarkedet (Petit 2007; Christensen 2000; Widerquist 1999). Hidtidige modtagere af overførsler skal ligeledes mægtiggøres i deres relation til velfærdsstaten med en ubetinget ydelse, ligesom ydelsen skal forene grupper, der hidtil har været adskilt i forskellige systemer, hvilket skal styrke deres muligheder for interessevaretagelse (Handler \& Babcock 2006; Van Parijs 1997). På arbejdsmarkedet skal ydelsen også ændre magtrelationen mellem arbejdsgivere og -tagere (Standing 2017; Vanderborght 2006). Helt simpelt skal ydelsen tilbyde en exit-mulighed fra arbejdsmarkedet (hvilket også kan være delvist i form af færre arbejdstimer) ved siden af exit til andre jobs, samt øge mulighederne for voice, idet man f.eks. kan se borgerlønnen som en potentiel strejkestøtte (ligesom en troværdig trussel om exit skal øge arbejdsgivernes villighed til at lytte til voice) (Birnbaum \& De Wispelaere 2016; Handler \& Bacbcock 2006).

Ovenstående argumenter er især anvendt i den nuværende debat om truslen fra automatisering, selvom det mulige fremtidige omfang af dette naturligvis er noget usikkert (Manyika m.fl. 2017; Arntz, Gregory \& Zahn 2016; Frey \& Osborne 2013). Debatten har ganske vist stået på siden industrialiseringens begyndelse, men surveys blandt eksperter i kunstig intelligens forventer ret transformative forandringer i de kommende årtier (Grace et. al. 2017; Smith \& Anderson 2014). Uanset fremtidsudsigterne anvendes borgerlønnen også som problemløsningsredskab i debatten om, hvorvidt flere aktuelt oplever usikre vilkår som følge af forandringer af både arbejdsmarked og velfærdsstat. Heller ikke denne debat er ny, og diagnoserne har været mange, men aktuelt diskuteres det især under begrebet prekarisering (Jacobsen \& Petersen 2017; Rasmussen \& Madsen 2017; Standing 
2014). Den lignende debat om segmentering eller dualisering mellem insidere og outsidere er også relevant, idet disse grupper ligeledes er defineret ved forskellige niveauer af sikkerhed i relationerne til både stat og marked (Emmenegger m.fl. 2012).

På trods af alt dette er de etablerede fagbevægelser som regel ret kritiske over for borgerlønnen, og det gælder ligeledes i Danmark (Christensen 2017; 2000; Vanderborght 2006). Af og til møder borgerlønsforkæmpere denne kritik med argumenter om at fagbevægelsen sidder fast i den industrialistiske arbejdskamp, og at den selv er afhængig af de nuværende koblinger mellem indkomst og arbejde. Der er dog gode argumenter for, at en borgerløn ikke løser alle problemer med arbejdsmarkedseksklusion, og at den under alle omstændigheder ikke ville kunne stå alene.

Lad os fokusere på de nævnte muligheder for exit og voice, da de taler direkte til argumenterne i borgerlønsdebatten, og dermed hjælper os med at fokusere de generelle debatter om prekarisering eller segmentering mellem insidere og outsidere. Mulighederne for voice og helt eller delvis exit fra arbejdsmarkedet vil også være ulige efter en borgerløn (Birnbaum \& De Wispelaere 2016). Mulighederne for exit fra et job til et andet vil selvfølgelig afhænge af efterspørgslen på forskellige former for arbejdskraft. Hvis denne også i fremtiden medfører en øget segmentering mellem forskellige kvalifikationer, og prekariatet vokser i størrelse, vil borgerlønnen ikke i sig selv løse dette problem på det lønnede arbejdsmarked. Hvis ydelsen bliver tilstrækkelig høj til at udgøre en troværdig trussel om, at arbejdskraften kan vælge helt at trække sig fra arbejdsmarkedet, vil arbejdsgivernes reaktion på voice-krav fortsat være påvirket af mulighederne for substitution med anden arbejdskraft eller automatisering. Hvis man får håndteret problemet med at finansiere en generøs borgerløn, og tilstrækkelig mange forlader arbejdsmarkedet, vil man muligvis forringe arbejdsgivernes muligheder for blot at finde anden villig arbejdskraft fra prekariatets rækker, men det vil også øge udfordringen ved at finansiere en borgerløn.

Tilskyndelsen til at forlade arbejdsmarkedet vil ligeledes være ulige fordelt uanset den konkrete indretning af borgerlønnen. På grund af eksempelvis løn og arbejdsforhold vil vinderne eller insiderne på arbejdsmarkedet generelt have færre tilskyndelser til exit fra arbejdsmarkedet.

Hvis insiderne eller vinderne fortsat har de bedste muligheder for at skifte til andre jobs, mens outsiderne kan benytte sig af forbedrede muligheder for at forlade arbejdsmarkedet, vil borgerlønnen medvirke til at polarisere brugen af de forskellige former exit (Birnbaum \& De Wispelaere 2016). Segmenteringen mellem insidere og outsidere vil således bestå, men den vil i højere grad handle om beskæftigede versus ikke-beskæftigede snarere end en skelnen mellem forskellige arbejdsforhold på arbejdsmarkedet. Det kan betvivles, hvorvidt dette vil ophæve de oplevede statusforskelle mellem dem, der har lønnet beskæftigelse, og dem, der ikke har.

En lav borgerløn, der ikke giver reelle muligheder for exit, vil derimod gøre voice til outsidernes eneste håb om forbedringer. Insiderne vil i stedet (fortsat) have bedre arbejdsforhold samt muligheder for exit til andre attraktive jobs, og dermed bliver brugen af voice-handlinger isoleret til bunden af arbejdsmarkedet, hvilket kan reducere deres 
gennemslagskraft. Denne problematik vil også være relevant med de nuværende tendenser og velfærdssystemer, men et ydelsesniveau, der er lavere end i dag, vil naturligvis ikke bidrage positivt til at løse den. Her vil en lav borgerløn, der gives uafhængig af beskæftigelse, kunne ses som udtryk for beskæftigelsesstøtte, der blot skal understøtte lavtlønsjobs og afhjælpe samspilsproblemer (høje sammensatte marginalskatter). Denne form for kritik har netop været rettet mod det aktuelle finske eksperiment fra den finske venstrefløj og fagbevægelse (Tiessalo 2017).

Ovenstående scenarier er noget stiliserede, og det vil givetvist være mere komplekst på tværs af segmenter og sektorer efter en borgerløn. Pointen er, at borgerlønnen ikke vil virke uafhængigt af andre drivkræfter på arbejdsmarkedet. Man kan naturligvis stadig argumentere for, at en tilstrækkelig borgerløn skal være et værdigt, ikke-stigmatiserende alternativ til beskæftigelse i fremtiden, men den kan ikke i sig selv afgørende bidrage til at løse segmentering blandt beskæftigede. Når det gælder beskæftigede versus ikke-beskæftigede, hvor attraktive jobs og lønninger fortsat er en mulighed for den ene gruppe, vil statusforskelle og stigma kunne udspringe af ulige beskæftigelsesmuligheder uanset tilstedeværelsen af en ubetinget indkomst. Nogle forkæmpere erkender, at borgerlønnen i stedet kan bidrage til at understøtte eller øge segmentering, og Gorz (1992) har eksempelvis beskrevet dette som borgerløns-apartheid.

Borgerlønnen er således ikke et columbusæg, der kan stå alene, og nok ikke engang det væsentligste redskab til at imødegå de problemer, der diskuteres i tiden. De skal imødegås på anden vis. Komparative analyser af atypisk eller prekær beskæftigelse har typisk understreget, at Danmark hidtil har været forskånet de problemer, der kan ses i andre økonomier, selvom tendenserne kan ses i visse brancher (Rasmussen, Larsen \& Andersen 2017). Der er grund til at bibeholde (og revitalisere) den danske og nordiske model, hvor velfærdspolitik og aktiv makroøkonomisk politik ses i sammenhæng med korporatistisk arbejdsmarkedsregulering på baggrund af høj organisering (Dølvik, Goul Andersen \& Vartiainen 2017; Rommetvedt 2017). På den anden side vil heller ikke dette være et i sig selv tilstrækkeligt svar, hvis fremtiden vil gøre det umuligt at fastholde en relativt høj beskæftigelse.

\section{Konklusion}

Hvis man lægger et konservativt perspektiv med udgangspunkt i eksisterede skattekilder og -niveauer, kan man trods alt argumentere for, at en borgerløn er realiserbar. Det ville blive en delvis udgave, hvor man kombinerer en ret lav borgerløn med reducerede udgaver af traditionelle velfærdsydelser for at sikre sig, at man ikke øger fattigdommen dramatisk. Alligevel vil det blive yderst vanskeligt at indføre en nogenlunde omkostningsneutral borgerløn og samtidig undgå, at hidtidige modtagere af overførsler ikke stilles ringere end i dag, især i et land som Danmark. Der er til en vis grad et dilemma mellem ydelsesniveauet, altså borgerlønnens tilstrækkelighed, og dens umiddelbare realiserbarhed. Den indkomstgraduerede, negative indkomstskat, som er den anden store idé om et 
alternativ til den eksisterende ydelsesstruktur, ville være nemmere at realisere på kort sigt. Idéen er kun blevet overfladisk inddraget i denne artikel. Med sit ikke-universelle fundament og sit fokus på at sikre en mindsteindkomst for de fattige, er den negative indkomstskat tættere på det, vi allerede kender, og hviler ikke på samme måde på frigørende eller libertære ambitioner.

En fuld og generøs borgerløn, der erstatter alle traditionelle overførsler, kræver skatteindtægter på et helt andet niveau end i dag. Dette er en del af selve pointen for mange venstreorienterede borgerlønsforkæmpere, idet borgerlønnen skal være redskab for omfattende makrostrukturel omfordeling for igen at kunne øge ligheden. Med blik på nogle af de tidligere eksempler er det dog noget svært at forestille sig nye idéer til beskatning af kapital, mv., der ikke samtidig vil få afledte negative effekter for almindelige indkomster. Uanset dette indeholder mange både nye og gamle borgerlønsforslag markant højere beskatning af også almindelige personindkomster.

Den delvise borgerlønsmodel kan forekomme noget skuffende, men som nævnt er der borgerlønsforkæmpere, der vil realisere idéen med dette første skridt. I tråd med den generelle velfærdshistorie vil man så kunne skrue op for ambitionerne, hvis det senere bliver økonomisk og politisk muligt at nå frem til steder, der indledningsvist forekom radikale og utopiske. Hvis man lægger de praktiske finansieringsbarrierer til side kan man endvidere argumentere, at der er et særligt gode implementeringsmuligheder i velfærdsstater, hvor der allerede er et historisk fundament for omfattende og relativt universel velfærdspolitik (Martinelli \& De Wispelaere 2017; Loftager 1994)

Alligevel skal det understreges at borgerlønnen ikke er noget columbusæg, der i sig selv kan løse problematiske tendenser og fremtidige bekymringer med hensyn til prekarisering og arbejdsmarkedssegmentering. Borgerlønnen fungerer ikke uafhængigt af andre drivkræfter, der afgør mulighederne (eller mangel på samme) på arbejdsmarkedet. Selv den fulde og generøse borgerløn kan have sine problemer, i tilgift til finansieringsbarrieren. I fremtiden vil der derfor stadig være brug for aktive og behændig politikførsel, hvis disse problemer skal håndteres.

I forlængelse af dette kan det derfor diskuteres, hvor højt man egentlig burde prioritere en borgerløn, hvis man endelig finder redskaberne til markant højere omfordeling. Det er banalt at konstatere, at der også på andre områder til stadighed er omkostningspres på velfærdsstaten. Nogle af målene vil givetvis og delvist kunne realiseres med mere begrænsede midler. Det nuværende sikkerhedsnet kan reformeres i andre retninger end den, der har præget de seneste årtier, hvis man har den diagnose (og man får skabt opbakning til den), at kravene og pligterne er blevet for mange og bureaukratiske, og sikkerhedsnettet for hullet. I den modsatte ende af kronologien var der endog borgerlønslignende karakteristika på tværs af overførselsindkomsterne, som de så ud inden 1990ernes bølge af arbejdsmarkedsreformer (Andersen \& Pedersen 2007). I Danmark har vi fortsat få medborgere, der står helt uden indkomst fra arbejde eller sikkerhedsnet, og i en sådan kontekst vil det være langt mindre omkostningsfuldt at gøre indhug i denne gruppe med eksiste- 
rende eller nye ikke-universelle ydelser efter kendte forskrifter. Tendensen har dog i stedet været, at gruppen er vokset i kølvandet på de senere års velfærdsreformer (Arbejderbevægelsens Erhvervsråd 2018).

Konklusionen er dermed, at borgerlønnens ønskværdighed afhænger af udgangspunktet for ambitionerne. Hvis man fra et lettere teknokratisk udgangspunkt vil bekæmpe aktuelle problemer og bekymrende tendenser, er en borgerløn ikke nødvendigvis det naturlige svar. Borgerlønnen skal vinde støtte på de større normative fortællinger, som denne artikel kun nødtørftigt har nævnt. Spørgsmålet bliver derfor, om offentligheden efterspørger nye og større ambitioner for frihed og retfærdighed end dem, vi hidtil har kendt, eller om borgerne i stedet ønsker hverdagspolitik, der skaber tryghed og sikkerhed $i$ en usikker verden.

\section{Litteratur}

Andersen, J.G. og Pedersen, J. (2007). Continuity and Change in Danish Active Labor Market Policy: 1990-2007. CCWS Working Paper No. 2007-54

Andersson, J.O. (2009). Basic Income from an Ecological Perspective, Basic Income Studies, årg. 4(2), s. 1-8. https://doi.org/10.2202/1932-0183.1180

Arbejderbevægelsens Erhvervsråd (2018). 160.000 personer er ikke i job eller uddannelse og får ikke understøttelse. København: Arbejderbevægelsens Erhvervsråd

Atkinson, A. (1996). The Case for a Participation Income. Political Quarterly, årg. 27(1), s. 67-70. https://doi.org/10.1111/j.1467-923X.1996.tb01568.x

Acarons, J., Pañella, D.R. og Mèlich, L.T (2014). Feasibility of Financing a Basic Income. Basic Income Studies, årg. 9(1), s. 79-93 https://doi.org/10.1515/bis-2014-0005

Arntz, M., Gregory, T. og Zierahn, U. (2016). The Risk of Automation for Jobs in OECD Countries: A Comparative Analysis. OECD Social, Employment, and Migration Working Papers no. 189. https://doi.org/10.1787/1815199X

Barry, B. (2001). UBI and the Work Ethic. I: P. Van Parijs, ed., What's Wrong With a Free Lunch? Boston: Beacon Press, s. 24-55

BIEN Danmark (2017). Finansiering af basisindkomst. Tilgængelig på: http://basisindkomst.dk/finansiering-af-basisindkomst/ [Tilgået d. 20. december 2017]

Birnbaum S. og de Wispelaere, J. (2016). Basic Income in the Capitalist Economy: The Mirage of Exit from Employment. Basic Income Studies, årg. 11(1), s. 61-74. https://doi.org/10.1515/bis-2016-0013

CESifo (2003). CESifo DICE Report 4/2003 (Winter). München: CESifo.

Christensen, E. (2000). Borgerløn. Fortoellinger om en politisk idé. Højbjerg: Hovedland.

Christensen, E. (2017). På vej til borgerløn-aktuel idédebat. Gjern: Hovedland.

Christensen, E. og Ydesen, C. (2007). Indledning. I: E. Christensen, K. Lieberkind og C. Ydesen, red., Retten til basisindkomst. Aarhus: Aarhus Universitetsforlag, s. 9-24 
Danmarks Statistik (2017). Person- og familieindkomster. Tilgængelig på: http://www.dst.dk/da/Statistik/emner/arbejde-indkomst-og-formue/indkomster/person-og-familieindkomster [Tilgået d. 20. december 2017]

Dohmen, T. (2014). Behavioral Labor Economics: Advances and Future Directions. Labor Economics, årg. 30, s. 71-85. https://doi.org/10.1016/j.labeco.2014.06.008

Dølvik, J. E.; Andersen, J.G. og Vartiainen, J. (2017). The Nordic Social Models in Turbulent Times: Consolidation and Flexible Adaptation. I: J.E. Dølvik og A. Martin, red., European Social Models from Crisis to Crisis. Employment and Inequality in the Era of Monetary Integration. Oxford: Oxford University Press, s. 246-286

The Economist (2017a). The "Free" Economy Comes at a Cost. The Economist, årg. 424 (9055), s. 63.

The Economist (2017b). Why Taxing Robots is Not a Good Idea. The Economist, årg. 424(9057), s. 59

Emmenegger, P., Hausermann, S., Palier, B. og Seeleib-Kaiser, M. (2012). How We Grow Unequal. I: P. Emmenegger, S. Hausermann, B. Palier og M. Seeleib-Kaiser, red., The Age of Dualization. The Changing Face of Inequality in Deindustrializing Societies. Oxford: Oxford University Press, s. 3-26

Larsen, R. E. (2002). Forord. I: R.E. Larsen, red., Oprør fra bredden. Fra velfordsstat til borgerløn. København: Tiderne Skifter, s. 7-14

Flassbeck, H. (2017). Universal Basic Income Financing and Income Distribution - The Questions Left Unanswered by Proponents. Intereconomics, årg. 52(2), s. 80-83. https://doi.org/10.1007/s10272-017-0650-2

Frey, C.B. og Osborne, M. (2013). The Future of Employment. Working Paper. Oxford: Oxford Martin School.

Goodin, R.E. (2001). Work and Welfare. Towards a Post-productivist Welfare Regime. British Journal of Political Science, årg. 31(1), s. 13-39. https://doi.org/10.1017/S0007123401000023

Gorz, A. (1992). On the Difference Between Society and Community and Why Basic Income Cannot by Itself Confer Full Membership. I: P. van Parijs, red., Arguing for Basic Income. London: Verso, s. 45-57

Gorz, A. (1997). Reclaiming Work: Beyond the Wage-based Society. Cambridge: Polity Press.

Grace, K., Salvatier, J., Dafoe, A., Zhang, B. \& Evans, O. (2017). When Will AI Exceed Human Intelligence? Evidence from AI Experts. Tilgængelig på: https://arxiv.org/abs/1705.08807 [Tilgået d. 17 oktober 2017]

Handler, J. og Babcock, A.S. (2006). The Failure of Workfare: Another Reason for a Basic Income Guarantee. Basic Income Studies, årg. 1(1), s. 14-37. https://doi.org/10.2202/1932-0183.1000

Hanlon, J., Barrientos, A. og Hulme, D. (2010). Just Give Money to the Poor: The Development Revolution from the Global South. Boulder: Kumarian Press. 
Harvey, J.T. (2011). Money Growth Does Not Cause Inflation! Tilgængelig på: https:/www.forbes.com/sites/johntharvey/2011/05/14/money-growth-does-notcause-inflation/\#58f7ec2542f5 [Tilgået d. 17. oktober 2017]

Höglund, M. (2007). Ekonomiska och politiska överväganden. I: E. Christensen, K. Lieberkind og C. Ydesen, red., Retten til basisindkomst. Aarhus: Aarhus Universitetsforlag, Aarhus, s. 355-378

IMF (2017). Fiscal Monitor October 2017: Tackling Inequality. Washington: IMF.

Jacobsen, M.H. og Petersen, A. (2017). Fagre nye arbejdsliv?. Tidsskrift for Arbejdsliv, årg. 19(1), s. 10-28. https://doi.org/10.7146/tfa.v19i1.109075

Kela (2016). From Idea to Experiment - Report on Universal Basic Income Experiment in Finland. Kela Working Papers no. 106, Helsinki: Kela.

Kela (2017). Basic Income Experiment 2017-2018. Tilgængelig på: https://www.kela.fi/web/en/basic-income-experiment-2017-2018 [Tilgået d. 19. oktober 2017]

Kamenica E. (2012). Behavioral Economics and Psychology of Incentives. Annual Review of Economics, årg. 4(1), s. 427-452. https://doi.org/10.1146/annurev-economics-080511-110909

Kongshøj, K. (2015). Den nordiske velfærdsmodel: Veje til og fra universalisme i Danmark, Finland, Norge og Sverige. I: C.A. Larsen og J.G. Andersen, red., Den universelle velfordsstat. Funktionsmåde, folkelig opbakning og forandring. Frederiksberg: Frydenlund Academic, s. 159-178

Loftager, J. (1994). Citizens Income and the Crisis of the Welfare State. General Reflections and a Danish Perspective. Aarhus: Institut for Statskundskab.

Manyika, J., Chui, M., Miremadi, M., Bughin, J., George, K., Wilmott, P. og Dewhurst, M. (2017). A Future that Works: Automation, Employment, and Productivity. Bruxelles: McKinsey \& Company.

Martinelli, L og de Wispelaere, J. (2017). A New Universalism? Varieties of Basic Income and Welfare State Reform. Konferencepaper præsenteret ved ESPAnet 2017, Lissabon.

Major, A. (2016). Affording Utopia: The Economic Viability of a "Capitalist Road to Communism. Basic Income Studies, årg. 11(2), s. 75-95. https://doi.org/10.1515/bis-2015-0023

McFarland, K. (2017). Current Basic Income Experiments (and Those So Called): An Overview. Tilgængelig på: http://basicincome.org/news/2017/05/basic-incomeexperiments-and-those-so-called-early-2017-updates/ [Tilgået d. 5. november 2017]

Miller, A. (2017) A Basic Income Handbook. Edinburgh: Luath Press.

Meyer, N.I., Petersen, K. H. og Sørensen, V. (1978). Oprør fra midten. København: Gyldendal.

OECD (2017). Policy Brief on the Future of Work - Basic Income as a Policy Option. Can it Add Up? Paris: OECD Publishing. 
Petit, P. (2007). A Republican Right to Basic Income?. Basic Income Studies, årg. 2(2), s. 1-10. https://doi.org/10.2202/1932-0183.1082

Rasmussen, S., Larsen, T.P. og Andersen, P.T. (2017). Det prekære arbejdsliv - en indledning. Tidsskrift for Arbejdsliv, årg. 19(1), s. 5-9. https://doi.org/10.7146/tfa.v19i1.109074

Rasmussen, S. og Madsen, P.K. (2017). Platformsøkonomien og prekariatet. Tidsskrift for Arbejdsliv, årg. 19(1), s. 46-62. https://doi.org/10.7146/tfa.v19i1.109077

Rankin, K. (2012). New Zealand: Prospects for Basic Income Reform. I: M.C. Murray \& C. Pateman, red., Basic Income Worldwide. Horizons of Reform. Basingstoke: Palgrave Macmillan, s. 200-226

Reed, H. og Lansley, S. (2016). Universal Basic Income: An Idea Whose Time Has Come? London: Compass.

Rhodes, C. (2017). Funding Basic Income through Data Mining. Tilgængelig på: http://basicincome.org/news/2017/01/funding-basic-income-data-mining/ [Tilgået d. 18. oktober 2017]

Rommetvedt, H. (2017). Scandinavian Corporatism in Decline. I: O. Knutsen, red., The

Nordic Models in Political Science. Challenged, But Still Viable? Bergen: Fagbokforlaget, s. 171-192

Rothstein, B. (2017). Solidarity, Diversity, and the Quality of Government. I: K. Banting og W. Kymlicka, red., The Strains of Commitment. Oxford: Oxford University Press, s. 300-326

Smith, A. og Andersen, J. (2014). AI, Robotics, and the Future of Jobs. Washington: Pew Research Center.

Standing, G. (2014). The Precariat: The New Dangerous Class. London: Bloomsbury Academic.

Standing, G. (2017). Basic Income, and How We Can Make it Happen. London: Pelican.

Tiessalo, R. (2017). Free Money Provokes Some Finns to Slam Basic Income as 'Useless'. Tilgængelig på: https://www.bloomberg.com/news/articles/2017-02-08/useless-basic-income-trial-fails-test-at-biggest-finnish-union [Tilgået d. 30. oktober 2017]

Zucman, G. (2017). How Corporations and the Wealthy Avoid Taxes (and How to Stop Them).Tilgængelig på: https://www.nytimes.com/interactive/2017/11/10/opinion/gabriel-zucman-paradise-papers-tax-evasion.html [Tilgået d. 17. november 2017]

Vanderborght, Y. (2006). Why Trade Unions Oppose Basic Income. Basic Income Studies, årg. 1(1), s. 1-20. https://doi.org/10.2202/1932-0183.1002

van Parijs, P. (1990). The Second Marriage of Justice and Efficiency. Journal of Social Policy, 19 (1), s. 1-25. https://doi.org/10.1017/S0047279400017827

van Parijs, P (1997). Real Freedom for All: What (if Anything) Can Justify Capitalism?, Oxford: Oxford University Press.

Widerquist, K. (1999). Reciprocity and the Guaranteed Income. Politics and Society, årg. 27(3), s. 386-401 
Widerquist, K. (2005). A Failure to Communicate: What (If Anything) Can We Learn from the Negative Income Tax Experiments? Journal of Socio-Economics, årg. 34(1), s. 49-81. https://doi.org/10.1016/j.socec.2004.09.050

Widerquist, K. og Sheahen, A. (2012). The United States: The Basic Income Guarantee - Past Experience, Current Proposals. I: M.C. Murray og C. Pateman, red., Basic Income Worldwide. Horizons of Reform. Basingstoke: Palgrave Macmillan, s. 1132

Widerquist, K., Vanderourght, Y., Noguera, J.A. og de Wispelaere, J. (2013). Introduction: The Idea of an Unconditional Income for Everyone. I: K. Widerquist, J.A. Noguera, Y. Vanderbourght og J. de Wispelaere, red., Basic Income. An Anthology of Contemporary Research. West Sussex: Wiley Blackwell, s. xiii-xxv 